総説 化粧品の化学的防腐についての諸問題

\title{
Problems of the Chemical Preservation of Cosmetics
}

\section{Gregor SCHUSTER*}

\author{
訳 小 林 正夫块
}

地球上の我々の現在の生活は，いろいろな形で「微生 物」なしでは存在しえない。人類と動物と植物との相互 共存といらことは, 数限りなく行なわれている。「微生 物」は食物入手のため, またその準備のため補助的な役 割をするものである。「微生物」は薬の様な価值ある代 謝物をつくるが, また事実上墓掘りの役をも演じてい る。しかし, 自然界において墓掘りという仕事を確実に やるこれらの「微生物」が無防備な食物, 薬品, 化粧 品, または他の基質を襲つた場合, それらの微生物はま たこれらの製品を完全に破壊してしまらかもしれない。

\section{1. 防腐の目的}

化粧品の防腐の目的は細菌もしくは酵素が起す好まし から変質を防止し，または減少させることである。も 乙「微生物」が化粧品製造中に持込まれ，好まし、生存 条件に恵まれるとしたら，何ら特別な方法を講じない限 り，それらは急速に倍加してゆく。そしてそれら微生物 の新陳代謝のために必要とする物質は, 微生物の代謝の 最終製品となってしまうのである。かようにその変化は 眼に見えず，また覚知し得ないとしても，こうした作用 の結果は, 新らしい製品の運命を厳しく物語るものであ り, 本来意図された産物とは全く異ったものとなってし まうのである。化粧品の防腐関するす心゙ての方法は微 生物が死滅するかまたは好ましからぬ副作用が起らない 程度にまで成長を抑止してしまう状態をつくり出寸試み にもとづいてなされているものである。そしてその化粧 品の本来の特質を保有しておくことの重要性を常に考慮 に入れておかね水ならないのである。いらまでもないこ とであるが持込まれた菌に生存条件を与えない様な製品 には防腐の必要がない。したがって次に述べることは微 生物の成長が起るような製品にとってのみ役立つもので ある。我々が防腐の方法を論じる前に, 問題は, むしそ の化粧品が微生物に緦好な生存条件を与えるとしても，

* Chemishe Fabrik Grünau 研究所所長 7918 Illertissen, Bavaria, West Germany （グリューノ一化学工業株式会社）

** 永和物産株式会社
まずその化粧品に防腐手段を行なうことが，必要かどう かが明らかにされなければならない。

\section{2. 防 腐の必要 性}

\section{$2 \cdot 1$ 使用者の保護のため}

従来微生物に污染された化粧品は, 使用者にとって危険 をもたらすものと信じられていた。こうした考えは今も $っ て$ D. G.F. (German Scciety for Fat Science) $の$ “科 学的化粧品” の専門的グループXIによって主張されて いる。それは 1968 年 3 月 2 日ハンブルグで行なわれた 化粧品の融和性試験に関する討論中 Mr. H. Wagner が 化粧中の菌の含有量決定について論じて以来のことであ る1)。F.Heiss は市販の 129 の化粧品の菌の含有数を テストしてその中の 32 の化粧品に, 異った種類の微生 物を発見した2)。O.H.Paetzold による Kiel の皮膚 病病院で行われた外来患者についての試験では, 菌は試 験品目のらちの $17.1 \%$ 中に見出された 3 。 。それによる と病源菌の非病原菌に対寸る割合は $56.1 \%$ に対する 43.9\% であった。J. Meyer-Rohn によれば4), 化粧品に 対する防腐が不正確または，不充分な場合にはバクテリ アの増加を促がすことにもなり，使用者たちに禍をもた らすおそれがあるかもしれないといつている。こうした 一連の情報を考慮に入れた G. Hopt の菌のいない化粧 品の製造についての報告は5)，一応理解できる。これは D. G.F. に於ける講演者たちの意見である。しかしなが ら 1967 年のハンブルグでの “Society of German Cosmetic Chemists” の会議での論議は, 上述のも のとは異っていた。A.Proppe は皮膚科学的見地から，

無菌の “EXTERNA”を不適切なものと考えた6)。そ れは“EXTERNA”にとって感染の焦点は皮膚それ自身 であるからである。H. Knothe は, 皮膚自体微生物に対 しすぐれた清浄作用をもち, それは非病原菌より病原菌 の方に一層働き易いことを指摘した ${ }^{7)}$ 。皮膚の保護手段 のためとして化粧品に無菌を要請するのは全く理由が立 たないように思われる。この概念の結論としては, 使用 者保護のため，化粧品を微生物の成長からまもることは 必要ないといらことになる。しからば，我々はなぜ防腐 
の問題について考えるのであろらか？ 今までに污染し た化粧品を試験し, またはこれを救った化学者の誰しも から，“化粧品を保護するため”といら答えが即座には ねかえってくるであろう。現実には化粧品中の菌の含有 を公式に制限する試みがなされており，スエーデンは既 にこの方法を採用した。

\section{$2 \cdot 2$ 化粧品の保護}

もし化粧品中に微生物がもちこまれたとすると，もし 防腐が不充分のためにその繁殖が自由におこなわれた場 合, その化粧品の一般的性質は, その微生物の新陳代謝 によって変わってしまらのである。その污染の出かたは 多種多様である。エマルジョンは沈澱しクリームやロ一 ションはカビを発生するかもしれないし, 部分的な変色 が起ることもあり, きれいな製品は沈澱のために濁った りする。また醱酵の為チューブが膨張しガラス瓶が破壊 したりする。その製品の良い匂いが腐敗臭に変わるかも しれない。その他の諸作用として微生物には, 脂肪を腐 敗させてしまら傾向があるものもある。高いコストをか け，あらゆる注意を払、信頼されてつくられた製品も， 売れなくしてしまうのである。それ故，化粧品の防腐と いらことは製造メーカーの損失を避けるために, 必要欠 くべからざることである。

\section{3. 防腐の方法}

化粧品の品質の防腐に関して, 我々が検討しようとい う方法にはいろいるある。

\section{$3 \cdot 1$ 物理的防腐法}

\section{$3 \cdot 1 \cdot 1$ 加熱による防腐法}

殺菌の過程中, 化粧品の中にいる微生物は熱の作用で 殺されるか，または，生存可能条件下で成長できないと ころまで傷ついてしまらかのいずれかである。しかしな がら，化粧品業界においては，この方法を採ることに対 しては厳しい反対がある。主な障害は容器に充塡される ばかりとなった製品は, 熱の影響を受け易いといら事実 である。多く化粧品は熱に対して敏感である。すなわち それらのエマルジョンは熱の作用によって沈洪し易く, したがって破壊されるのである。この種の殺菌性は密閉 された状態においてのみ保持される。パッキングを開封 した後の化粧品は（食品の場合とは反対に）短期間内に 直ちに使用されることがないということを考えると，使 用者はその品物が污染するか損傷するかの危険にさらさ れていることになる。

\section{$3 \cdot 1 \cdot 2$ 乾燥による防腐法}

水分の除去によって化粧品を損傷から守る可能性はさ らに一層出てくる。初から高度のパーセントの乾燥物質
を用いて化粧品をつくることはもちろん可能である。し かしながら多くの化粧品にとって水分は重要な原料であ るから，この方法はす心゙ての場合に応用はできない。

$3 \cdot 1 \cdot 3$ 冷却防腐法

もら一つの物理的防腐法が化粧品に用いられた。それ は冷却をして防腐をする方法 (Refrigerated Preservation) である。冷却防腐法は，温度が下がれば微生物 の生存能力を減じ, かつまたその増殖運動は, 低温発育 タイプの場合を除き, 零下 $10^{\circ} \mathrm{C}$ 以下の温度で止まって しまうといら事実に基くものである。

この方法は化粧品を冷蔵庫に貯蔵することを必要とす る。アメリカ合衆国では，この方法は特別の場合には可 能な有効な方法であることが既に立証されている。たと えば易取り化粧品が容器開封後, 冷蔵庫の中に保管され た例がある。

\section{$3 \cdot 1 \cdot 4$ 照射による防腐法}

或る種の光線が微生物を殺すということも著明なこと である。この照射処理に適する光線は， $\alpha$ 及び $\beta$ 線や紫 外線並びに X 線である。 $\alpha$ および $\beta$ や $\beta$ 線の殺菌的効 果は, 二次的反応を生ずる。化粧品 (Ionizing Rays) 中 の活性基の活動をひき出すことに基いている。この種の 光線はその浸透性効果のため, すでに容器に充填ずみの 化粧品にも応用することも可能である。他のすべての物 理的方法と同様, 品質の安定性は密閉によって保証され ているにしか過ぎず，それはパッケージが開封されるま でしかもたない。

しかしながら，紫外線はイオン化をもたらさない。微 生物に再び増殖できなくなる程度の損傷を与えるには， 紫外線はその製品の中心部にまで浸透するだけの量がな ければならない。しかし，この光線は浸透性が弱いため (製造現場では紫外線ランプを使用), 既に容器詰された 化粧品の防腐はもちろん, 細菌を非常に少なくする目的 にさえ適さない。

\section{$3 \cdot 1 \cdot 5$ 無菌的製造}

いかに意識的に物理的方法を応用してつくつた無菌化 粧品も, それは密閉状態を取り除かれ, 最初の損傷が起 きるまでしかもたない。無菌化粧品を製造するには，非 常に多くの問題点があるが，こうしたむずかしさはあま り熱心でない一部の人たちによって問題とされているに しか過ぎない。

無菌化粧品を製造するとき，おそらくだれしもが菌が微 量のものと考えているであろう。物理的防腐についての 最も重大な欠点はこの方法で処理されたものはその処理 の時点においてのみ，保護されているにしか過ぎないと いうことである。長期にわたる保護は密封によってのみ 
保たなければならないのである。

\section{$3 \cdot 2$ 化学的防腐}

化学的防腐の最大の利点は, 化粧品に化学的物質を添 加することによって，たとえ污染が幾たびか起ってもそ の物質が微生物の損傷から保護するということである。

物理的方法で防腐した化粧品には異物質（防腐剂）が 混入していないということが大きな長所である。しかし ながら化学的防腐による場合には防腐のための活性物質 がその製品の一部になっている。この事は同時にこの方 法のもつ最大の欠点でもある。これらの物質とは一体ど んなものであるか？

$3 \cdot 2 \cdot 1$ 化学的防腐剤の定義

防腐剤とは微生物によって起る化粧品の有害な変化を抑 止または，防衛するために投入される抗細菌的活性物質 である。

この工程においてその物質は化粧品の一部となる。そ れが微生物の成長を防衛する筈である。

\section{$3 \cdot 2 \cdot 2$ 微生物の成長}

微生物が繁殖後, 特異な通常の大きさに生長してゆく 過程について述べる。一般的に“成長”といら言葉は, あるタイプの菌の個々のものが繁殖することである。菌

Fig.-1 Phases of growth of Micro-organisms
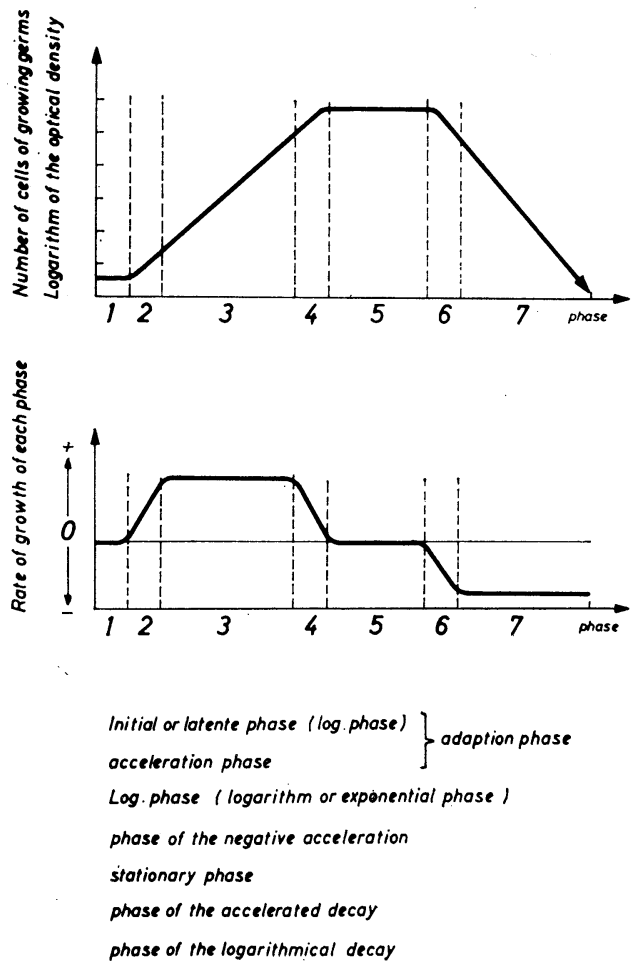

の成長は独特なカーブを描いて進んでゆく。それは種々 な過程にわかれる。(Fig. 1)

Buchanan によると帛，それれには 7 つ過程がある。

1. 初期または潜伏期

投入された微生物は, しばらくの間は繁殖しない。潜 伏期の長さはいろいろな要素による。すなわち植えられ た菌の若さやその量および栄養的手段によるのである。

2. 促 進 期

分裂はゆるやかに行なわれる。総体的にみて, 最初の 二つの過程は適応期とも, 呼ばれる。その菌はその環境 条件に従う。適応期の間においては, 分裂の割合は成長 の度合よりも低いのである。その結果, 平均的なサイズ の菌はその後の過程にあるときよりも一層殖えるもので ある。新陳代謝は活発になり, 生理的に若いこの段階に おいて, 細胞は殊に熱と寒さの衝撃や塩の濃度や防腐剤 に敏感である。

3. Log の過程 (Logarithmic of exponential phase)

この過程での成長は, 均一性をもってしかも急速な繁 殖を特色とする。繁殖は幾何学的な速度で起るから, 我 々は直ちに有毒な新陳代謝的産物が蓄積されていくのが わかる。またそれらが栄養的物質を欠いている姿や，ま た悪い特徴が変化してゆく姿も見られる。こうした要素 については次項に述べる。

\section{4. 減速度の過程}

栄養物の不足とか毒性のある代謝物の蓄積は, Log の 過程の終未を物語るものであり，それらは継続的に起る ものである。この理由のため, $\log$ の過程 (前項の過 程）は加速度的に変わるものであり，突然に定常な過程 に変わるわけではない。

5. 定常の過程

この過程にあるとき, ほぼ同数の菌が死に, そして増 殖する。かくして GERMS/ML の量は増殖を中止す る。液体培養における単位当りの含有菌の数は, 各タイ プについてほとんどコンスタントである。

6. コントロールが加速的に行なわれる過程

この過程にあっては, 菌は増殖する以上に死んで生存 菌の数は減少しはじめる。定常の過程は死減の Log の 過程と転換する。

\section{7. 死滅の $\log$ の過程}

この過程にあって微生物は非常に急速に死滅する。特 殊の菌が依然増殖するのみである。成長のカーブ (Fig.1) は生存菌を対象としている。細胞の合計数（生存菌お よび死滅菌の数) は最終過程にいくに従い増加してゆ <。 
$3 \cdot 2 \cdot 3$ 微生物についての防腐剤の効果

文献では微生物についての防腐剤の効果は, 次のごと く従来から述べられている。防腐剂の使用により可逆 (静菌或は静菌効果) 又は不可逆的な方法で微生物を損 傷させ，そしてそれを破滅させる。殺菌的効果について は微生物はしばらくの間は生存しているが, 増殖は不可 能になる。微生物が適当な媒体中にもどされると増殖は 再び開始される。こうした説明はたとえば Ullman の 1960 年度版の第 11 巻 442 頁に書かれている。保存は一 般に静菌能と静真菌剂とに分けられるに対して, 菌の増 殖の防止は殺菌能と殺菌剤によるべきである。 M. V. Schelhorn が行なった試験によると ${ }^{10)}$ ，好適な静菌作用， 静真菌効果は, 存在しないということである。 M. V. Schelhornによると, 安息香酸, サリチル酸, 覀硫酸ガ ス, 蟻酸等の防腐㓮も, 充分な量を添加すれば，短時間 で殺菌性を示すことが証明された。換言すればそれらの 物質は殺菌性を示し, 菌の増殖防止の性質をあらわす。 これらの物質の低濃度をもちいても, 殺菌作用は行はな われる。しかしそれは少し長時間後すなわち数時間, 数 日間, 数週間後迄行なわれるにしかすぎない。

もし防腐剂を添加した化粧品中に微生物が入るとした らどんなことが起るか?それは二つの可能性しかない。

もし製品中に含まれている防腐剂の量が充分なもので あるか, または, 活性であるならば, その化粧品は, も し外部からの新らしい污染が起らなければ，時が経過す ると無菌状態になる。効率的な防腐剤はいろいろな污染 から製品をまもり，その無菌性を持続するのである。完 全無菌性となるに必要な時間は, その防腐剤の効果によ ることになる。もし, ある防腐剤の殺菌活動がその防腐 剂が揮発性のため経時的に不活性になったり，必要な濃 度が稀釈によって減少すると, その段階でいまだ生存し ていた菌は再び増殖しはじめる。防腐剤の量が充分でな かったり，あるいは充分に活性でないとすると，微生物 の増殖は防腐剤の存在にもかかわらず起ってくるのであ る。防腐剤を少しも含まない試料に比べれば, この増殖 は遅くなっている。製品が防腐剂を多く含めぼ含むほ ど，効果は大きくなることは明らかである。不充分な防 腐しか行なわない上記のような場合には, その化粧品中 に細菌学的増殖が行なわれ, 菌の増殖は多少激しく起 る。菌はその化粧品から栄養的物質を吸収して, それの 代謝物質を化粧品に戻す。この場合二つの可能性があ る。その化粧品の成分に不特定の効果をもつかまたは特 定の効果を持つかは，含まれている細菌の種類によるの である。したがって，その変化は上記の兆候によって認 識されたり,されなかったりである。もし菌がつくり出
す酵素または代謝物質が化粧品の成分を変化させないと したら上記のプロセスは認識されずにすむ。また一方, もし微生物による酵素がその化粧品の成分に対し, 増殖 的或は破壊的作用を行なうとしたら，そのプロセスは認 識できる。その上，むし代謝物質が腐った臭を放ったり， ガス状であったり，そのパッキングをそこなったりする とそのプロセスははっきり認められる。防腐剤を含みか つまた, 微生物によって污染された化粧品は皆, あるプ ロセスすなわち殺菌作用か菌の増殖作用かいずれかのプ ロセスを経ているものである。しかしながら菌増殖に対 する抑止作用が純粋または単純に起きているような静的 な状態というのは，実際的にはどうしょうもない深刻な 事態なのである。

\section{$3 \cdot 2 \cdot 4$ 防腐剂の効率}

（1）培養基中の防腐羭の効率

これは方々の細菌学研究所で共通な方法を用いて決定 される。一方に拉いていろいろな菌の成長抑止に必要な 最低の濃度が決められ, 他方において, 同じ菌を殺すに 要した量が決められる。これらのテストの試験温度は, 通常 $37^{\circ} \mathrm{C}$ である。最初の数字は細菌発育防止のもので

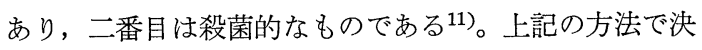
定される防腐剤の抗菌的効果に関する数字は専門家であ る我々を驚かせる。我々はたとえば, $1: 30,000$ の濃度 でのクロロヘキシレンが Pseudomonas pyocyanea の増 殖を抑止するし，また 1:17,500 の濃度においては, 10 分以内でこれらの菌の $99.9 \%$ を殺すといらことが知ら れている。1:17,500 といら数字は 5 グラムのクロロへ キシレンを 100 キログラムの製品に添加すると pseudomonas pyocyanea type の菌を約 $99.9 \%$ 殺すというこ とである。

（2）化粧品中の防腐剤の効果

充分な注意と努力によって確実に決められた上記の数 字を，容易に実行に移すことはできない。一般に防腐剤 は, 上述したよりもっと高度な濃度で用いられるもので ある。しかし製品の保護は必らずしも充分には達成でき ない。その原因は何であるか?この疑問は化学的防腐に 関する根本的問題を含んでいる。第一の理由は, 防腐剤 はしばしば放果が決められた時の系とは著しく違ら系で 使用されることであり，また第二としてはテストの温度 が化粧品の貯蔵温度に合致しないことである。

このことは化粧品の防腐効果についてより一層の興味 を起させる。

ある化粧品は次のものを含有する。

i) 製造業者により加えられる物質 (細菌学的見地から その製品の基質と考えられるもの)。 
ii）ある状態にあって，意図しないのに入ってしまっ たバクテリア。

iii）微生物を破滅するため, 製造業者が添加した防腐 剤。

この理由のため, 防腐の問題をこの因子を別々に考え ることは不可能であり，相互に影響しあうのである。

Fig. 2 の中で，これら 3 つの因子の相互作用についての 説明が試みられた。

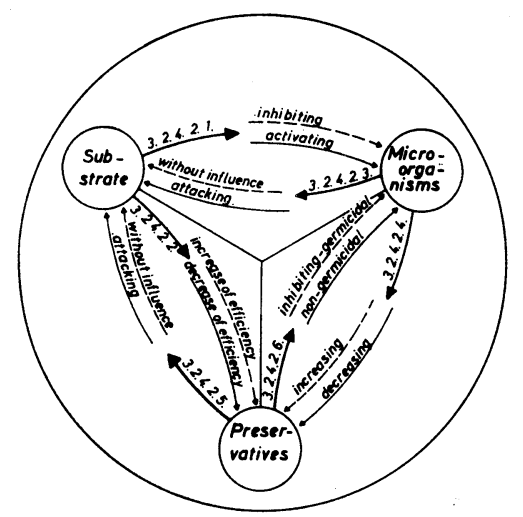

Fig.-2 Reciprocal effect of Substrate-Micro organisms-Preservatives

相反作用の可能性は大きなものであり, 次の約束が理 解できぬほどの多くの因子がある。こうした相反作用の ため, 化学的防腐のさいに起る複雑な様相をよく考察 し，それぞれの防腐する系に応じた適当な防腐㓮を探し てみなければならないのである。

\section{（A）基質一微生物の影響}

基質は微生物に詨し, 抑制的かつ活性的効果をもち得 るものである。基質は微生物に対し抑制的な働きをする 基質, その基質により与えられる生存条件が特殊な微生 物にとって普通の生存条件とちがえばちがうほど，その 抑制効果は強いのである。たとえばもし基質として一つ の製品の中に高濃度の乾燥性物質か高濃度溶液を含むよ うな場合がそれである。チオグリコールをベースとし た，たとえば「kaltwellösungen」，あるいは臭素のカリ ウム，ナトリウム塩をべースとした固着凨のような還元 あるいは酸化物質の溶液は強力に殺菌的作用を発揮する。 菌のアタックが強いにもかかわらず殺菌性は急速に作用 する。特に芳香族アミンや $\mathrm{pH} 9$ 以上のフェノールをべ 一スとした暗黒色の染毛剂は殺菌的に働く。芳香族アミ ンやフェノールを少量しか含まない明るい色調の染毛剂 は基剤により充分な殺菌的効果をもっている。
陽イオンまたは両性活性剤の殺菌効果は著しいものが あり，特別の効果を期待するでなければ，技術者はこう いう場合, 防腐剤をさらに使ったりするような技術的誤 りをおかす。15\% またはそれ以上のアルコールを含む 製品もまた充分な防腐効果を発揮する。グリセリンや 1,2 プロピレングリコールの量を増すと同様の効果を出 す。それゆえある防腐剤が必要かどらかを決めるために は，試験をやってみなければならない。基質の $\mathrm{pH}$ 值は， 微生物についての抑制的, または活性的効果に決定的に 影響を与える。 $\mathrm{pH}$ 值が中性点からちがえばちがうほど， 抑止的に働く。エーテル化した油もまた抑制的効果をも つといわれている。

基質はもしそれが次の理想的生存条件（すなわち高度 の水分, 中性的 $\mathrm{pH}$ 域, 低、塩濃度, アミノ酸の存在ぺ プタイド, ビタミン Bグループ, 少量のグリセリンの含 有, ソルビトールの含有）を与えるとしたら, 微生物に 対し促進的効果をもつものである。この場合, 防腐は特 に注意して行なわれなければならない。

\section{（B）基質一防腐剤の影響}

防腐剤に対する基質の影響は, 防腐剤の効率上, 極め て重要な意味をもっものである。

基質は防腐剤の効率を増すかもしれないがまた，ほと んど無効にしてしまうこともあり得る。基質の水素イオ ンはまたいろいろな防腐㓮の, 効率に大いに影響しやす い。防腐㓮は 3 つのグループに分けることができる。そ れらの化学構造によると, もし基質の $\mathrm{pH}$ が酸性である ときだけ活性である防腐剤と基質の $\mathrm{pH}$ が中性まで低く なっても響影の少ない防腐㓮と, 最後に $\mathrm{pH}$ 值に無関係 な防腐剤である。防腐剤としての使用される酸は第一の グループに属する。すべてのパラオキシ安息香酸エステ ルは, いろいろなフェノール誘導体と同様第二のグルー プに属する。 $\mathrm{pH}$ 值と無関係なものはホルムアルデヒド とホルム寄与物質である。防腐剤効果をもつ酸の抗菌性 効果のある担体は, 非解離遊離酸だけである。それは非 解離遊離酸がイオンよりもよい脂溶性をもっているから である。非解離遊離酸の量は, 酸の解離定数によるもの であり,したがって $\mathrm{pH}$ によるものである。

Table 1 は防腐剂的活動をする酸の解離定数のことを 述べている。すべての非解離の部分は, 塩素, 酸, を除 き $\mathrm{pH}$ 值が増加すると減少する。したがって酸を $\mathrm{pH} の$ 中性域のものの防腐㓮として用いてはならない。

ある文献とは反対であるがパラオキシ安息香酸エステ ルの効果は, $\mathrm{pH}$ 值が増加すると減少することを指摘し たい。それは石炭酸誘導体や有機水銀化合物のごときで ある。それゆえ，我々は効果的な作用をもつ要因として， 
Table-1 Disscciation of preservatives acids depending on the $\mathrm{pH}$ value at room temperature (by S. W. Souci)

\begin{tabular}{|c|c|c|c|c|c|c|c|}
\hline \multirow{2}{*}{ Preservative acids } & \multirow{2}{*}{$\begin{array}{c}\text { Dissociation } \\
\text { constant }\end{array}$} & \multicolumn{6}{|c|}{ hon dissociated aktive Substance in $\%$ at } \\
\hline & & $\mathrm{pH}=2$ & $\mathrm{pH}=3$ & $\mathrm{pH}=4$ & $\mathrm{pH}=5$ & $\mathrm{pH}=6$ & $\mathrm{pH}=7$ \\
\hline Sulphur dioxide & $1.7 \cdot 10^{-2}$ & 37 & 5.5 & 0.55 & 0.04 & 0.001 & 0 \\
\hline Bromacetic acide & $5.05 \cdot 10^{-3}$ & 83 & 32.8 & 4.65 & 0.48 & 0.049 & 0.0049 \\
\hline Salicylic acid & $1.06 \cdot 10^{-3}$ & 90 & 49 & 8.6 & 0.94 & 0.094 & 0.0094 \\
\hline formic acid & $1.77 \cdot 10^{-4}$ & 98.3 & 85 & 36.1 & 5.35 & 0.56 & 0.056 \\
\hline p Chlorobenzoic acid & $9.3 \cdot 10^{-5}$ & 99 & 91 & 52 & 9.7 & 1.06 & 0.107 \\
\hline Benzoic acid & $6.46 \cdot 10^{-5}$ & 99.3 & 93.9 & 60.7 & 13.4 & 1.52 & 0.15 \\
\hline p Hydroxybenzoic acid & $3.3 \cdot 10^{-5}$ & 99.7 & 96.8 & 75.2 & 23.2 & 2.94 & 0.30 \\
\hline Acetic acid & $1.8 \cdot 10^{-5}$ & 99.8 & 98.2 & 84.7 & 35.7 & 5.26 & 0.55 \\
\hline Sorbic acid & $1.73 \cdot 10^{-5}$ & 99.8 & 98.3 & 85.2 & 36.6 & 5.46 & 0.57 \\
\hline propionic acid & $1.4 \cdot 10^{-5}$ & 100 & 99 & 88 & 42 & 67 & 0.71 \\
\hline Dehydrocetic acid & $5.3 \cdot 10^{-6}$ & 100 & 100 & 95 & 65 & 15.8 & 1.9 \\
\hline Hydrogene sulphite & $1.02 \cdot 10^{-7}$ & 100 & 100 & 99.9 & 99 & 90.7 & 49.5 \\
\hline acid boric & $7.3 \cdot 10^{-10}$ & 100 & 100 & 100 & 100 & 100 & 100 \\
\hline
\end{tabular}

微生物に対し抑制的効果をもつ基質の組成を考えること ができる。(A参照) それらの組成のため， o/w タイプ のエマルジョンは微生物に対しては, 理想的な基質であ る。な拉, 実際の二つの相すなわち, 油と水は, 多くの 水に難溶性の防腐剤の効果を少なくする。この理由は, これらの防腐剤の水への難溶性と油への易溶性のため

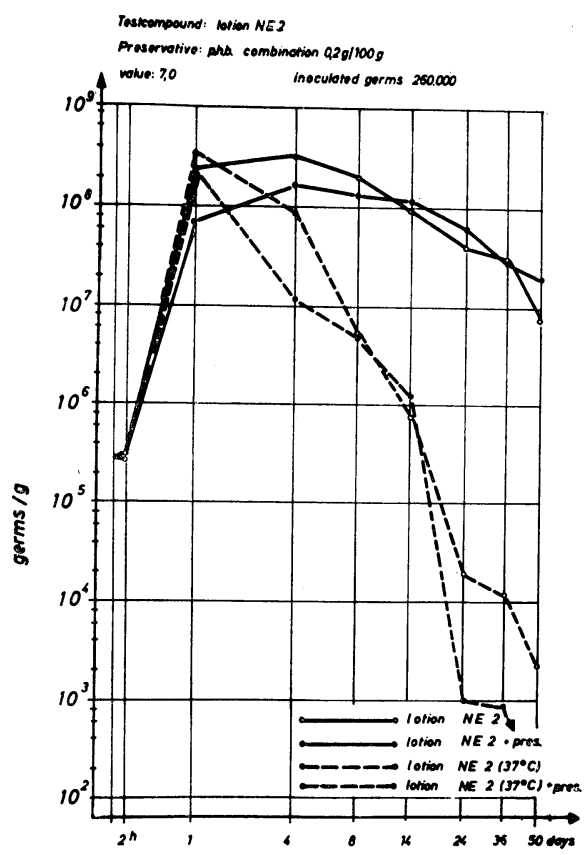

Fig.-4 Efficiency of Preserveatives
（それはそれ等の分散係数のせいである。）後者は油相に 集まる。重なる。したがって防腐剤は水相の保護のため には役立たない。しかしながら w/o 型のエマルジョン は, 污染に対し比較的安定している。なぜならば外相で ある油相は, 微生物が水相中に移動したり, 水相から出 てくるのを防禦するからである ${ }^{12)}$

Fig.-3 では非イオン o/w-エマルジョン中における菌 の発育のことを説明している。

防腐的な措置をしていないあるエマルジョンは, $0.2 \%$ のパラオキシ安息香酸エステルで保護されたエマルジョ ン同様, 約 260,000 細菌/G（グラム陰性およびグラム陽 性の菌の混合液) で污染されており，室温での菌の成長 が認められた。防腐したエマルジョン中の菌の成長は, 防腐措置をしてないエマルジョンに比べて，ごくわずか 減少しているにしかすぎない。著しいのは室温（18～ $\left.24^{\circ} \mathrm{C}\right)$ と $37^{\circ} \mathrm{C}$ のもとに貯えられたエマルジョンの間の 両者のちがいである。

化粧品中の多くの成分は, 困難な水溶性防腐剤の効果 を減らす。非イオン界面活性剤によるパラオキシ安息香 酸エステル類や, 他のフエノール誘導体の不活性化はよ く知られており，多くの著者によって試験された。

Fig.-4 では非イオン系乳化剂による防腐剤の不活性 化についての洞察を試みている。

パラオキシ安息香酸エステル類 $0.2 \%$ の量は $0.5 \%$ の GO-12(脂肪酸アルコール ポリグリコールエーテル HLB 值 12）に含まれる菌を殺すに充分であった。しか しもっと高濃縮溶液中にあっては菌の増殖が起った。す 


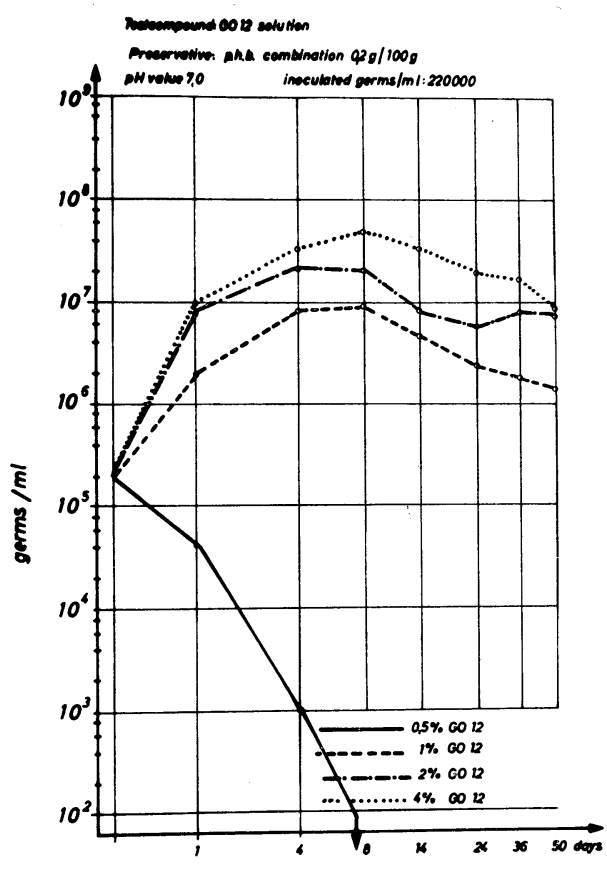

Fig.-4 Efficiency of Preservatives

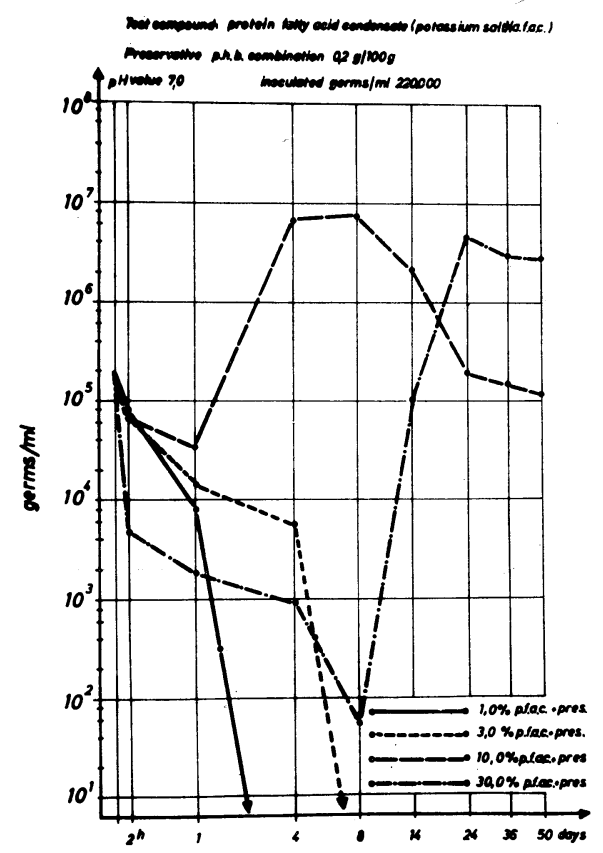

Fig.-5 Efficiency of Preservatives

なわち GO-12 の濃度が高ければ高い程, 増殖はさらに 一層烈しい。陰イオン界面活性剤もまたこれらの防腐剤
を不活性にする14)。

CFG (蛋白脂肪酸縮合物の製造者) は，本問題につい て詳しい試験を行い，興味ある結果を得た。

Fig.-5 では， $0.2 \%$ のパラオキシ安息香酸エステル類 で保護された異なる濃度におけるカリ塩溶液一蛋白脂肪 酸縮合物中の菌の増殖を実証している。1\% および $3 \%$ の溶液中では, 菌の激減が認められ, 殺菌は達成された。 しかし 10\% 及び 30\% の溶液は菌の著しい成長を示し た。

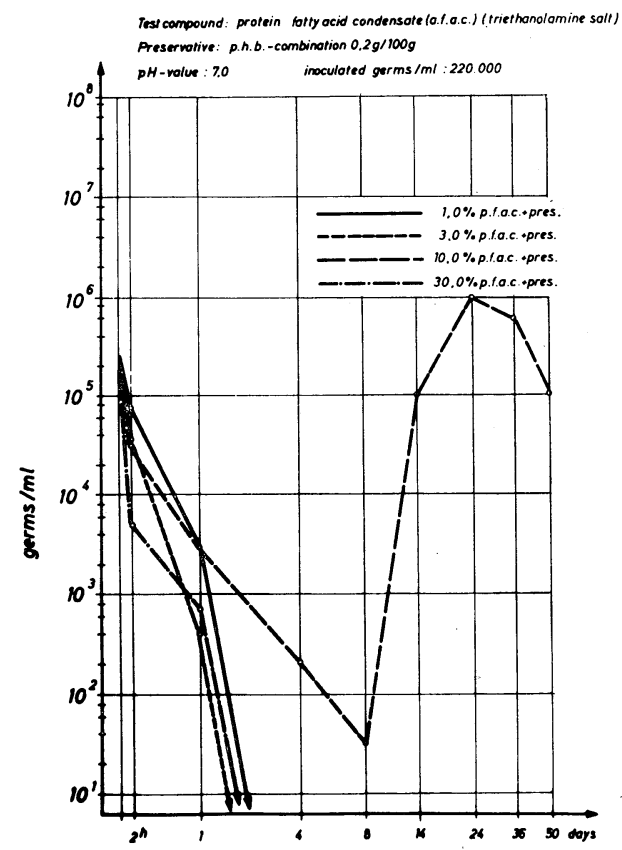

Fig.-6 Efficiency of Preservatives

Fig.-6 では, Fig.-5 と同条件で蛋白脂肪酸縮合物卜 リエタノールアミン塩でのテストの結果を説明する。殺 菌は 1, 3 および $30 \%$ 溶液で成功したが, $10 \%$ 溶液で は当初の減少後に著しい菌の増殖が起った。

Fig.-7-8 では, 蛋白脂肪酸縮合物のカリウムおよび フリエタノールアミン塩溶液について得られたテストの 結果を示す。 $(0.3 \%$ のパラークロロメタクレゾールを 用う)

しかしながら，両方の界面活性剤グループは，D.L. Wedderburn ${ }^{15)}$ が非イオン性界面活性剤について Schuster および Modde が陰イオン性界面活性剤につ いて，それぞれ実証したごとく，界面活性剤と防腐剤の 間の初期の段階で不活性となるにしかすぎない。もし一 


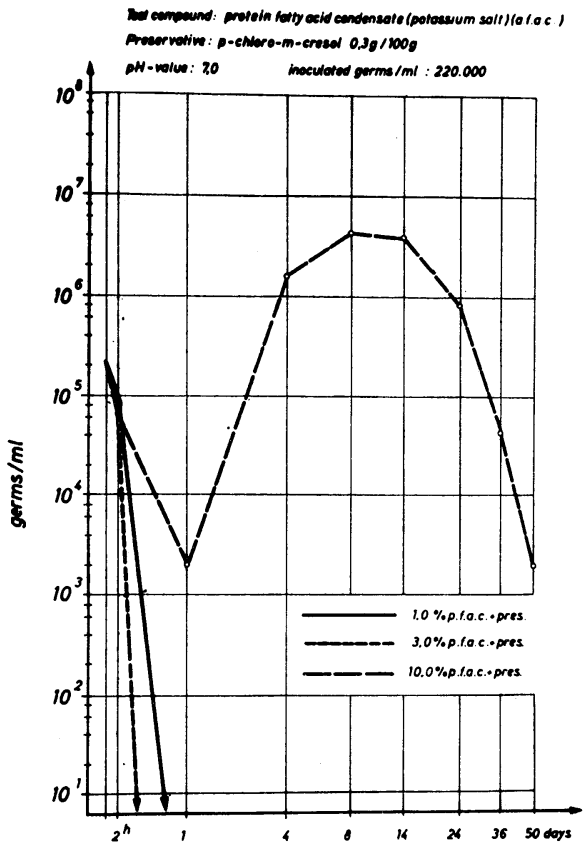

Fig.-7 Efficiency of Preservatives

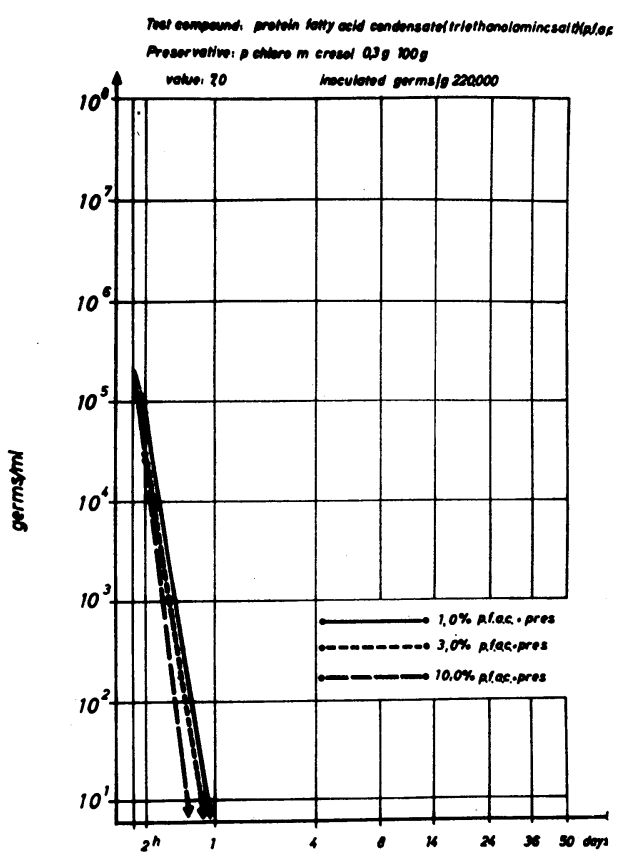

Fig.-8 Efficiency of Preservatives

Table-2 Evaluation of the test results for the determination of the ratio ratio $=\frac{\text { Tenside Concentration }}{\text { Preservative Concentration }}$

\begin{tabular}{l|c|c|c|c|c|c|c|c}
\hline \multicolumn{2}{c|}{ Preservative } & \multicolumn{2}{|c|}{$\begin{array}{c}\text { Sodium Lauryl } \\
\text { Sulphate }\end{array}$} & \multicolumn{2}{c|}{$\begin{array}{c}\text { Potassium Salt } \\
\text { of the Protein } \\
\text { Fatty Acid Cond. } \\
\text { ratio }\end{array}$} & \multicolumn{2}{c}{$\begin{array}{c}\text { Triethanolamine } \\
\text { Lauryl Sulphate }\end{array}$} \\
& $\mathrm{g} / 100 \mathrm{~g} / 100 \mathrm{~g}$ & $\mathrm{~g} / 100 \mathrm{~g}$ & ratio & $\mathrm{g} / 100 \mathrm{~g}$ & ratio \\
\hline $\begin{array}{l}\text { p-chloro } \\
\text { m-cresol }\end{array}$ & 0.1 & 3.0 & $\frac{3.0}{0.1}=30$ & 3.0 & $\frac{3.0}{0.1}=30$ & 8.0 & $\frac{8.0}{0.1}=80$ \\
\hline $\begin{array}{l}\text { pHB-ester } \\
\text { combination }\end{array}$ & 0.3 & 9.0 & $\frac{9.0}{0.3}=30$ & 9.0 & $\frac{9.0}{0.3}=30$ & - & - \\
\cline { 2 - 6 } & 0.3 & 3.0 & $\frac{3.0}{0.2}=15$ & 6.0 & $\frac{6.0}{0.2}=30$ & $>10.0$ & $\frac{>10.0}{0.2}=>50$ \\
\hline
\end{tabular}

定量の防腐剤を与えた場合, 界面活性剂の濃度の限度, すなわち菌が始めて成長をはじめる限度が決定されると したら，そしてまたさらに防腐剤に対する界面活性剤の 計算上の濃度の商が, 求められるとしたら次の関倸が得 (Table 2) られる。すなわち Schuster および Modde によればそそれは effect figure と呼ぶものである。

この効果の表以上においては，防腐剤はどんな効果も 生み出さない。またこの effect figure 以下に扔いて, 防腐剤が選ばれた濃度下にあって有効であるなら，それ
は充分に有効なものとみてよい。

この兆候は水に難溶性の防腐剤が，ミセルと水相の間 で分散係数によって抎散した系中の独立した相と考えて 説明することもできる17,18)。これは非イオン界面活性 剤中にあって水素結合の形成によって活性化される。公 開はされなかったが，厳重な試験の結果，フエニール醋 酸水銀の効率が非イオン性抒よび陰イオン性界面活性剂 によって害なわれることが知られた。上述の界面活性剂 や o/w の二相系の他に次のような巨大分子化合物は防 
腐剤の効率を抑止する。それはトラガント, アラビアゴ ム, メチルセルローズ, ポリビニールピロリドン, カル ボポール 934 ${ }^{19)}$, 高分子ゼラチンおよび他の高分子化合 物である。これらの化合物は皆, 水に接するとゲルを形 成する。したがって二相中の膨潤した高分子/水は防應 剤の防腐効果の減退を説明しうる。

誤って調整した基質の $\mathrm{pH}$ 值は効率を減少させる。し かしながら, 防腐剈のあるものは, 基質によってマイナ スには影響されない。これはホルマリンやホルマリン寄 与物質の場合である。それらは Eckhardt'20)によれば, 今日では依然として防腐の難しいものに使用されている。

\section{（C）微生物一基質の影響}

微生物によって基質から分離した代謝物や酵素は, 基 質に影響したり，侵蝕破壊したりしないかもしれない。 詳細は $2 \cdot 2$ および $3 \cdot 2 \cdot 3$ 参照。

しかし, 微生物によって分離した代謝物が，基質に防 腐的衝きをする場合がある。

(D) 微生物一防腐剤の影響

微生物は, 分離した代謝物により, 防腐剤に活性的ま たは不活性的に作用するかもしれぬ。基質中の防腐剤の 不活性化は決して全体にわたるわけではない。ある効果 は維持されるのである。ただし, この残余の効果は微生 物の増殖を防ぐには充分ではない。もし代謝物が，基質 の $\mathrm{pH}$ 域を, その防腐剤の理想的有効な AREA の方へ

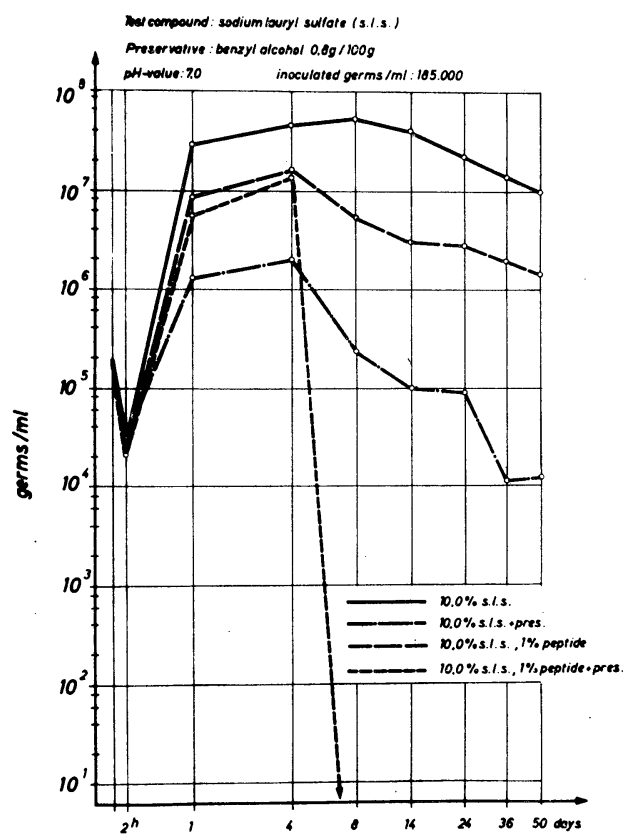

Fig.-9 Efficiency of Preservatives

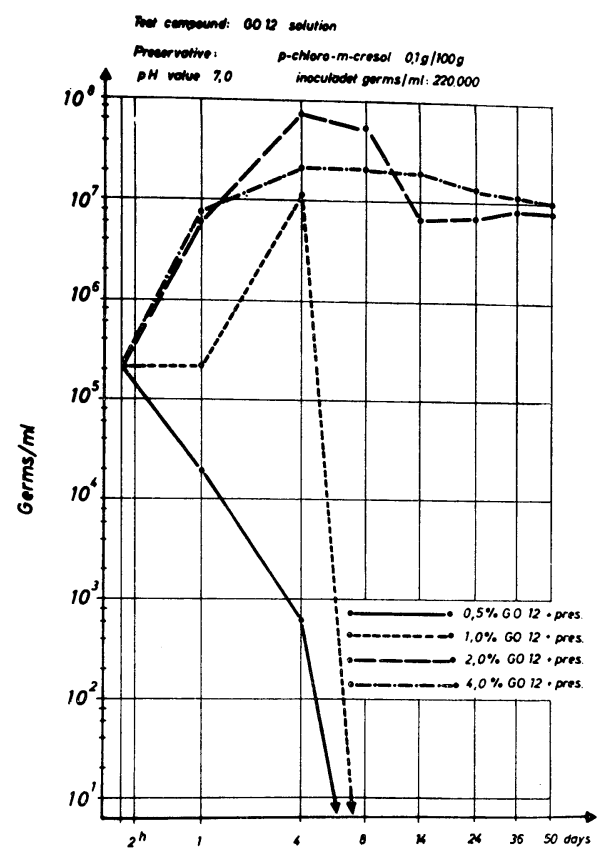

Fig.-10 Efficiency of Preservatives

移動させるなら，この $\mathrm{pH}$ 変動によって生じる効果性の 増加は急速に殺菌的作用を行わしめるには充分である。 今一つの可能性は, 微生物により予め分離され成長能力 のある菌を殺す有毒な物質を, 添加して防腐剤の不充分 な効率を強化することであろう。

Fig.-9-10 に扔いては，そうした効果を包含する試験 結果が再現されている。

著しい当初の菌の増殖後, 突如として殺菌的結果をもた らした菌の激減が起っている。

一方に扔いて, 緑濃菌には栄養源としてパラオキシ安息

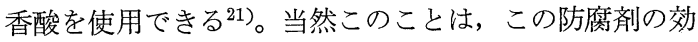
果には役にたたない。

ある防腐テストでは, 微生物が防腐剤について不活性 的に㗢くという印象を与える。最初ある相当量の微生物 は防腐剤の効果によって破壊されるが, 残余の菌は再び 増殖を始めることが観察される。この結果は, 微生物に よるその化合物の分解のためか, あるいは抵抗力のある 菌ができるためか, そしてまたどの程度までかというこ とは未だ判明しない。防腐されるべき製品の感染が烈し く, かつ, 多様性をもてばもつほど, 防腐凨が相当量入 っているにもかかわらず，特別に抵抗力のある菌は堌殖 するのである。

一方に括いて, 微生物の存在数と防腐凨の必要量との間 には，明らかになんら直接の関連性はない。いいかえる 
と，極めて少数の微生物の破壊のためには，極く少量の 防腐剤を必要とするという，なんらの確証もないのであ る。

（E）防腐剂一基質の影響

ある防腐剤は，基質によって力を発揮する。ある場合 には，基質は防腐剤による影響は陰性である。このこと は明らかにときどき起き得ることである。それは，基質 と防腐剤との成分間の反応がいろいろな可能性を生むた めである。ホルムアルデビドはアミノグループを含む化 合物と反応し得ること, 又は亜硫酸塩がアルデヒドグル ープと反応し得ることである。一方において，これらの 防腐剤は，反応性をむつこれらのグループが消失レてい る基質に非常に有効である。

硫化水銀は基質にフェニール醋酸水銀を加える時に得 られる。二つの基質の濃度により，時期がたっと硫化水 銀は基質を濁った乳白色から，強いあるいは果実臭を伴 った黒い防腐剤に変えることがあるかもしれない。すな
わち、ジメトキサンが基質の匂いを変える。

これらの例は起り得る影響に関し，ヒントを与えるもの

であるにしかすぎない。

（F）防腐㓮一微生物の影響

防腐剤は微生物に対し抑止的または破壊的に作用し得 る。これが防腐剂の期待される効果である。この理由の ため, 防腐剤は微生物に適切な生存条件を与える化粧品 に添加される。

しかしながら，防腐剤の微生物に対する効果は，防腐 剤の所期の効果を発揮するまでに, 微生物への作用を停 止する程度まで種々の因子により減退することもある。 この場合, 防腐剤は化粧品の不要部分として考えられそ して，その処方中の防腐剤の存在はまったくとるに足ら ない存在である。研究者はこれらのものを完全に省略す るなり，効果的な他の防腐剤を探す心゙きである。

防腐剂はその系の他の成分によって，ある程度のとこ ろまで影響される。その程度は細菌培養基を試験して得

Table-3

Effciency of various preservatives in the test compound at $\mathrm{pH}$ of 7

trial temperature $18 \sim 25^{\circ} \mathrm{C}$

Test compound

\begin{tabular}{|c|c|c|c|c|c|c|c|c|c|c|c|}
\hline & & & & & rva & & & & & & \\
\hline $\begin{array}{l}\overrightarrow{0} \\
0 \\
0 \\
0 \\
0 \\
1 \\
1 \\
1 \\
0 \\
0 \\
0 \\
\overline{1} \\
0 \\
1 \\
0\end{array}$ & 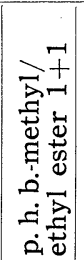 & 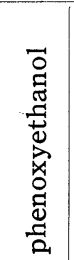 & 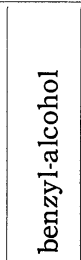 & 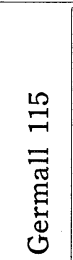 & 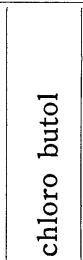 & 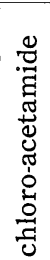 & $\begin{array}{l}8 \\
8 \\
: \overline{0} \\
0 \\
0 \\
0\end{array}$ & 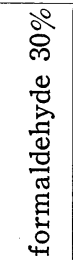 & 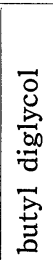 & 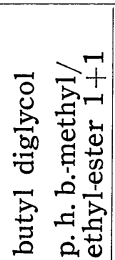 & 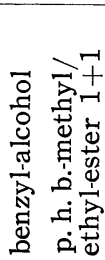 \\
\hline$\left|\begin{array}{cc}0 & 0 \\
8 & 8 \\
0 & 8 \\
\hdashline & - \\
0 & 0 \\
-1 & m \\
0 & 0\end{array}\right|$ & $\left|\begin{array}{cc}\infty & 0 \\
8 & 8 \\
0 & 8 \\
\hdashline & \multicolumn{1}{c}{} \\
\infty & 0 \\
N & 0 \\
0 & 0 \\
0 & 0\end{array}\right|$ & 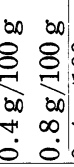 & $\left|\begin{array}{cc}\infty & \infty \\
8 & 8 \\
& 8 \\
\hdashline & - \\
0 & \infty \\
+ & \infty \\
0 & 0\end{array}\right|$ & 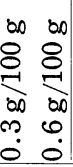 & $\left|\begin{array}{cc}0 & 0 \\
8 & 8 \\
8 & 8 \\
\hdashline & - \\
0 \infty & 0 \\
+ & \infty \\
0 & 0 \\
0 & 0\end{array}\right|$ & $\begin{array}{c}\infty \\
8 \\
0 \\
00 \\
10 \\
0\end{array}$ & $\left|\begin{array}{cc}0 & 0 \\
8 & 8 \\
8 & 8 \\
-1 & -1 \\
00 & 80 \\
-1 & m \\
0 & 0\end{array}\right|$ & \begin{tabular}{cc}
60 & 0 \\
8 & 8 \\
8 & 8 \\
\hdashline & 9 \\
000 & 00 \\
10 & 0 \\
-1 & 0 \\
0 & 0
\end{tabular} & $\underbrace{\infty}_{-1}$ & 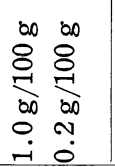 & 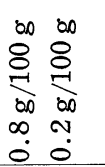 \\
\hline $\begin{array}{ll}+ & + \\
+ & +\end{array}$ & $\begin{array}{ll}+ & + \\
+ & +\end{array}$ & -+ & $\begin{array}{l}-+ \\
-+\end{array}$ & -- & $\begin{array}{ll}+ & + \\
+ & +\end{array}$ & - & $\begin{array}{l}++ \\
-+\end{array}$ & & + & & \\
\hline
\end{tabular}

\section{$1 \%$ polypeptide}

$35 \%$ polypeptide

$10 \%$ protein fatty acid condensate

$10 \%$ protein fatty acid condensate $1 \%$ polypeptide

$10 \%$ sodium lauryl sulfate

$10 \%$ sodium lauryl sulfate

$1 \%$ polypeptide

$3 \%$ emulsifier GO 12

$3 \%$ emulsifier GO 12

$1 \%$ polypeptide

lotion $\mathrm{NE} 1$

lotion $\mathrm{NE} 1\left(37^{\circ} \mathrm{C}\right)$

lotion NE 2

lotion $\mathrm{NE} 2\left(37^{\circ} \mathrm{C}\right)$

Explanation of marks: +effective, inoculated germs are killed -without effect

\pm inoculated germs are not killed within 50 days 
られた殺菌の数字が，ある物質が抗菌的に活動するなら ば検出を助ける手掛りとなる限度までの範囲である。

新しい物質の抗菌的効果についての文献によると, 我 我としては研究者達が少なくとも10倍も既存の化合物の 効果を出すために，一種の競争をやっているというよう に思われる。防腐目的のためには，我々は $1: 1,000,000$ の抗菌効率をあげる物質は必要ではなく，0.1 0.5\%の 量で我々の製品を污損から守る様な物質を必要とするの である。問題はただ，「我々が化粧品中の防腐剤の効率 に関する正確な文献を，どうすれば提供することができ るか」ということである。G. Schuster は防腐的効果を

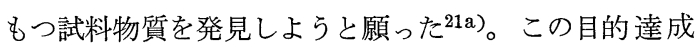
のため, 一連の試験化合物としてそれぞれ異った防腐剤 がそれぞれ異った量で混合され，そしてグラム陰性及グ ラム陽性の菌の混合物で污染させ。結局菌の成長を観察 した。

テストの結果は Table-3 に塔載されている。

$\mathrm{pH} 7$ に調整された $3 \%$ オレイルアルコール +8 ÄO （Emulsifier GO 12） および 1\% 蛋白加水分解物 (NUTRILAN L) の溶液は試料物質として用いた。この 試料物質における防腐剂の効率は, 化粧品の全部または 少なくとも大部分について詳細に説明している。ただし 陰イオン活性剤を含む化合物に，防腐剤として用いられ ている陽イオン化合物を除く。

\section{$3 \cdot 2 \cdot 5$ 包装材一防腐の影響}

今日まで出ている文献は, 化粧品の成分の相互作用の ことを扱っている。製造工程を経て化粧品は適当な容器 に詰められる。したがって，包装材と接触することにな る。

防腐剤に対する包装材の影響については, 防腐凨の水 溶液を用いて試験してはならない。反対に preserved system に基いて, 防腐剤と包装材との間の相互作用を テストしなければならない。Fig.-11 がこの相互作用を 説明するであるう。

ガラス, 瀬戸物や硬質アルミニウムチューブのよう な, 包装材の相互作用は別であるようだ。しかしながら 包装材として用いられたプラスチックは製品と相互作用 を起すことがあるし，したがって防腐郕と相互に作用し 合うことがある。プラスチックは，その化粧品に対しあ る物質を浸透させ，ある成分または，異物質（すなわち 酸素) のためにその化粧品に影響を及ぼすこともあり得 る。もちろんこれは，もし防腐牏または異物質（すなわ ちソルビン酸またはホルマリンのような酸化性防腐剤の 酸素）上にある物質のネガテブ作用が起るとしたら，防 腐剂の防腐効果を阻害するかもしれない。しかしなが

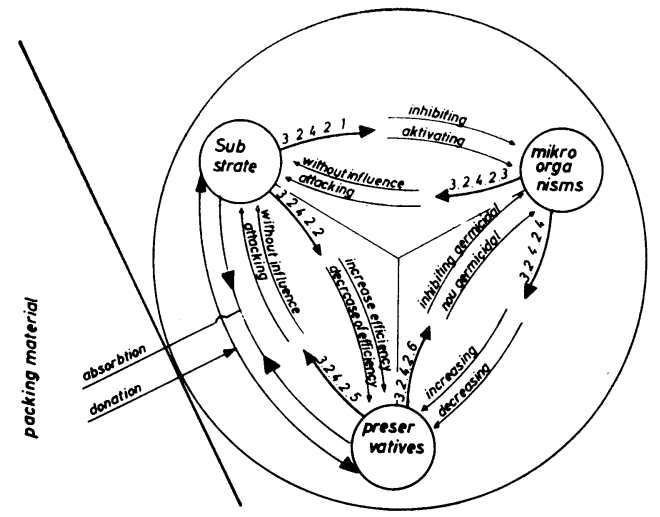

Fig.11 Reciprocal effect of Preservatives Packing material

ら，包装材として使用されるプラスチックが製品の基材 を取り上げてしまい，種々の成分の協力を阻害すること があるということを，知っておくこともまた重要であ る。

さて，防腐鼡が奪い取られるとすると，もし防腐剤の 量が効果の一定限度以上でないと, 製品の危険性が起っ てくる。

\section{$3 \cdot 2 \cdot 6$ 人間に対する防腐刘の影響}

むし，我々が，今日まで求めなられてきたあらゆる条 件を満足されるある防腐剤をみつけたとすると,さらに 進んだ問題が解決されるにちがいない。人間に㗢く防腐 剤の効果はどんなものであるか? その化学的性質のため, 殺菌剤の働きをする防腐剤は, 人間に無関係には㗢かないことは確実であるう。

1. 防腐㓮による刺激。

防腐した化粧品を繰返し使用する消費者は，防腐剤と して用いた物質によって起るアレルギーにかかることが ある。

1958 年, Schulheiss 24) はパラオキシ安息香酸エス テル類は，もし外用する場合には，刺激的な働きをする ことがあると始めて報告した。爾来, 同様の内容をもっ た数個の報告が公表された。N.Hjorth および，C. Trolle-Lassen は，パラオキシ安息香酸エステル類とは 別にソルビン酸や有機水銀化合物も使用者に対し刺激作 用をもっことがあると報告しいてる25)。F. Klaschka ${ }^{26)}$ もまた，刺激を起す防腐剤の中でホルマリンを分類して いる。

2. 皮膚相に対する影響。

防腐した化粧品の使用は, 量的にまた, 質的に皮覤相 を変えることをまずもって考慮に入れなくてはならない。 
このことは, 防腐剤は化粧品中にあって働くばかりでな く, また，皮膚にも衝くという議論で説明されている。 その結果としては菌の減少ということであり，皮膚菌 (グラム-陽性及グラム陰性) のいろいろ異った抵抗力に よって, また皮膚相の組成的変化を起させたり, 平準 な皮膚相を変化させることともなろら。Meyer-Rohn は22)健康人または病人の皮膚相の組成に関して報告して いる。しかしながら, 病人の場合は個人差が著しいし， また職業によっても違う。なおまた，個人的な清潔度も 関係してくる。G.Heiss ${ }^{23)}$ は，男性と女性の皮膚相の相 異について報告している。皮膚相は防腐剤の影響（もし 防腐剤の水溶液が皮膚に用いられた場合）で変化するこ ともある。

今日まで, 菌の減少について，またへキサクロロフェ ン石䶨やへキサクロロフェンスプレイのような, いわゆ る消臭剂とは反対に，防腐を施した化粧品の使用により 起る皮膚相の変化については, なんらの立証もなされて いない。しかしながら，これら両者とも，その構成に関 する限りに掠いて異っている。防腐された化粧品中の防 腐剤の比率は，その製品だけを防腐する量のところに止 めておくべきである。消臭剤に含まれているへキサクロ ロフェンや類以の活性物質のような菌防止の物質の比率 は, 皮膚の上において, 菌を減少させる必要な位重要な ことである。

皮膚上に絶えず残っている防腐剤を加えた化粧品の場 合には化粧品の成分は，皮膚菌にとって栄養物ともなる し，また，菌の減少とは反対にも働くということも考慮 に入れて置かなくてはならない。この理由のため消臭ス プレイは，菌に抵抗作用をする物質とは別に皮膚相に影 響し易いような他の物質を含んではいない。

\section{$3 \cdot 2 \cdot 7$ 化学的防腐剤の必要性}

1. 化粧品における抗菌性

最初に, 防腐剂というものは複雑な構造をもっ化粧品 中にあって, 菌に対する抵抗作用を行なわなければなら ない。換言すると，防腐剤は化粧品の成分による影響を 受けてはならないし，また，その影響もとるにたらない 程度のものでなければならない。さらに，防腐剤もその 化粧品中に容易に投入できるものでなければならない。

2. 副 作 用

その他, 防腐剤は化粧品の成分にも, また, 使用者の 皮膚にも副作用を起すようなものであってはならない。

皮膚上において，毒性のあるものやアレルギー反応を 起すようなものは望ましくない。

\section{LITERATURE}

1) H. H. Wagener, Vortrag anl. d. Vortrags-und Diskussionstagung der Fachgruppe XI der D. G. F. am 2.3. 1968 in Hamburg

2) F. Heiss, Fette-Seifen-Anstrichmittel 69, 365 369 (1967)

3) O. H. Paetzold, Vortrag anl. der D. G. F.-Vortragstagung in Mainz 1967

4) J. Meyer-Rohn, Fette-Seifen-Anstrichmittel 69, $536 \sim 538$ (1967)

5) G. Hopt, Diskussionsbeitrag anl. der D. G. F.Vortragstagung in Hannover 1966

6) A. Proppe, J. Soc. Chemists Cosmetic 18, 715 725 (1967)

7) H. Knothe, Referat anl. d. Vortrags-und Diskussionstagung der Gesellschaft deutscher Kosmetika-Chemiker e. V. (G. K. C.) in Hamburg 1967

8) G. A. Nowak, Seifen-Ole-Fette-Wachse 79, 161 164 (1953)

9) Buchanan, in Grundri der Medizinischen Mikro biologie von Kohler-Mochanann VEB Gustav Fischer Verlag Jena S. 40 (1964)

10) M. V. Schelhorn, Fette-Seifen-Anstrichmittel 56, 221-224 (1954)

11) F. Neuwald, Fette-Seifen-Anstrichmittel 69, 361 $\sim 365$ (1967)

12) L. F. Tice and M. Barr, J. Soc. Cosmetic Chemists $9,171 \sim 180$ (1958)

13) H. S. Bean, S. M. Heman-Ackha u. J. Thomas, J. Soc. Cosmetics Chemists 16, 15 26 (1965)

14) G. Schuster und H. Modde, Fette-Seifen-Anstrichmittel, 70, 169 174 (1968)

15) D. L. Wedderburn, J. Soc. Cosmetics Chemists, 9, $210 \sim 228$ (1957)

16) G. Schuster und H. Modde, Fette-Seifen-Anstrichmittel, 71, 394 399 (1969)

17) D. L. Dyer, Soap Chem. Specialities 34, 53 55, 139 (1958)

18) H. B. Kostenbauder, Amer. Perfumer Aromat. 75, No. 1, 28 33 (1960)

19) D. Guttmann und H. Higuchi, J. Amer. Pharmac. Assoc. Sci. Edit. 45, 659 664, 1964 
20) W. Eckardt, Parfumerie und Kosmetik 47, 295 $\sim 297$ (1966)

21) G. A. Nowak, Jahrbuch f. d. Praktiker, Verl. f. chem. industrie H. Ziolkowsky, Augsburg 61 69 (1967)

21a) G. Schuster, Seifen-Fetté-Ole-Wachse, Heft 20/ 21/24 (1968)

22) J. Meyer-Rohn, J. Soc. Cosmetic Chemists 17, $287 \sim 297$ (1966)
23) F. Heiss, Vortrag anl. d. D. G. F.-Vortagstagung in Mainz 1967

24) E. Schultheiss, Berufsdermatosen 6, 292 301 (1958)

25) N. Hjorth und C. Trolle-Lassen, American Perfumer 77, Jan. 43 46 (1962)

26) F. Klaschka, Fette-Seifen-Anstrichmittel 68, 756 $\sim 760$ (1968) 